\title{
Community in Native America: Continuity and Change among the Sioux
}

Raymond J. DeMallie

\section{OpenEdition}

\section{Journals}

Electronic version

URL: https://journals.openedition.org/jsa/10792

DOI: 10.4000/jsa.10792

ISSN: 1957-7842

\section{Publisher}

Société des américanistes

\section{Printed version}

Date of publication: 23 July 2009

Number of pages: 185-205

ISSN: 0037-9174

\section{Electronic reference}

Raymond J. DeMallie, "Community in Native America: Continuity and Change among the Sioux", Journal de la Société des américanistes [Online], 95-1 | 2009, Online since 10 June 2014, connection on 02 September 2022. URL: http://journals.openedition.org/jsa/10792 ; DOI: https://doi.org/10.4000/jsa. 10792 


\title{
COMMUNITY IN NATIVE AMERICA: CONTINUITY AND CHANGE AMONG THE SIOUX
}

\author{
Raymond J. DEMALLIE *
}

The idea of " community ", because it embodies the moral sense of a group integrated by common interest, is an important concept for understanding the social realities of American Indian life. In historical times, variations in community size and composition throughout the year brought about realignments of people according to seasonal activities. Since the creation of reservations, most American Indian communities have become sedentary, year-round settlements. This paper examines the Sioux Indians of the Great Plains ethnohistorically to track changes over time in the composition and meaning of community. In recent times, new definitions of community based on ideologies of blood and race are competing with older definitions based on kinship and face-to-face social interaction, common language, and common culture. [Key words: North American Indians, Sioux Indians, community, kinship, race.]

La communauté amérindienne : contimuité et changement parmi les Sioux. L’idée de " communauté », parce qu'elle incarne le sentiment moral d'appartenance à un groupe soudé par l'intérêt commun, est un concept important pour la bonne compréhension des réalités sociales de la vie des Amérindiens. Á l'époque historique, les variations de taille et de composition des communautés, au cours d'une année, étaient dues aux diverses occupations saisonnières des personnes. Après la création des réserves, la plupart des communautés amérindiennes sont devenues des établissements sédentaires l'année durant. Cette étude examine les Indiens sioux des plaines d'un point de vue ethnohistorique, afin d'établir les changements qui ont eu lieu dans la composition et la signification du terme "communauté ». Récemment, de nouvelles définitions de ce concept fondées sur les idéologies de sang et de race rivalisent avec les anciennes significations construites autour des notions de parenté, d'interactions sociales, de langage et de culture. [Mots-clés : Amérindiens, Amérique du Nord, Sioux, communauté, parenté, race.]

La comunidad en la América indigena : continuidad y cambio entre los siux. La idea de " comunidad ", porque incluye el sentido moral de pertenencia a un grupo ligado por interés común, es un concepto importante para entender las realidades sociales de la vida de los indígenas norteamericanos. En los tiempos históricos, las variaciones en el

* Indiana University, Department of Anthropology, Bloomington 47405, Indiana, USA [demallie@indiana.edu].

Journal de la Société des Américanistes, 2009, 95-1, pp. 185-205. O Société des Américanistes. 
tamaño de las comunidades durante el año generaba configuraciones variables según las actividades de la estación. Después de la formación de las reservas, la mayoría de las comunidades indigenas se volvieron sedentarias durante todo el año. Este artículo interroga los Siux de las grandes Llanuras en términos etnohistóricos para seguir los cambios en la configuración y el sentido de " comunidad ». En tiempos recientes, nuevas definiciones de la comunidad basadas en las ideologías de la sangre y de la raza competen con las más antiguas basadas en el parentesco, la interacción social, un idioma común, y una cultura compartida. [Palabras claves : indígenas norteamericanos, siux, comunidad, parentesco, raza.]

The term « community » is used widely and indiscriminately today in popular culture to lend an aura of social integration to what are perceived to be interest groups. Introducing a recent volume of anthropological essays on community, Gerald W. Creed (2006, p. 3) remarks: « Whether we see it as the nostalgic desire for a lost past or the creative reformulation of a postmodern society, the focus on community has become ubiquitous in the way we talk and think about life in the twenty-first century ». As Creed (2006, p. 6) suggests, the term « community » implies three constituent meanings: « a group of people, a quality of relationship (usually with a positive normative value), and a place/location ». Such groups may be based on race, ethnicity, religion, politics, interest, individual attributes, or almost any other characteristic. Invoking the term "community " implies commonality of purpose and, usually, opposition to some other group or groups. This metaphorical use of the term draws on the moral connotations of community as the term is defined in the social science literature.

In American anthropology, "community " as an analytical concept owes much to the work of Robert Redfield (1960, pp. 3-4), who developed his ideas in the context of his field studies of Mexican villages. He observed that « the small community has been the very predominant form of human living throughout the history of mankind ", and he identified four qualities that define the community: " distinctiveness, smallness, homogeneity, and all-providing self-sufficiency ». Redfield's « little community » reflects Emile Durkheim's concept of the « social segment ", held together by mechanical solidarity (that is, integrated by moral consensus) and characterized by a sense of the sacred (Redfield 1960, p. 142; Durkheim 1947). The direct inspiration for Redfield's perspective derived from his teacher, the sociologist Robert Park. As a result, Redfield's conception of community has a strong sociological grounding; it is most importantly a residential social unit whose members interact with one another face-to-face.

In prereservation Native North America the size of residential social units frequently varied widely according to the season, making the identification of communities somewhat complex. Among nomadic hunting groups, the smallest level of social organization - the extended family or band - was the residential unit throughout much of the year, while among semisedentary groups whose 
economy was based on horticulture or fishing, the village - a conglomeration of lineages - was the residential unit during a significant period of the year and provided a geographical locus for the social group. The colonial context of interaction with encroaching Euro-Americans, including population loss from disease, forced removals, and military conflicts, further complicated social organization. As a result, it is difficult to generalize about communities in Native North America. Each one is in some respects unique.

As an example of Native American communities I will focus on the Sioux (Lakota and Dakota Indians), who lived during the nineteenth century in a wide arc across the prairies and plains of North America from Minnesota to Montana. In the mid-nineteenth century their population numbered 30,000 to 40,000 individuals, of whom two-thirds were Lakotas (Tetons) who lived west of the Missouri River, and one-third were Dakotas (Yanktons/Yanktonais and Santees) who lived east and north of the Missouri (DeMallie 2001, p. 748). Taking an ethnohistorical approach, it is possible to chart significant differences in the definition of community among the Sioux as it changed over time: the prereservation period (ending in 1868), the early reservation period (to 1934), the period of the Indian Reorganization Act and Relocation (to 1961), and the period of self-determination (to the present). As one of the larger groups in Native North America, and one of the best documented historically and culturally, the Sioux can serve as an effective case study.

\section{The Prereservation Period (To 1868)}

\section{The Sioux as a social group}

Although the oldest historical sources, dating to the late seventeenth century, use the designation tribe, tribes, or nation to refer to the Sioux, these early writers do not characterize Sioux society as clearly bounded or politically integrated. In 1695, Pierre-Charles Le Sueur brought to Montréal a chief « of the Sioux who was the first in his nation who had ever been in Canada » to meet the French governor. The chief presented the governor with « as many arrows as there were Sioux villages ", asking that traders be sent to his people (Delisle 1702). Le Sueur noted that there were twenty Sioux villages and that all spoke the same language. The term village seems to suggest definite locations for these social groups, and, in fact, Le Sueur marked the locations of twenty-two villages on a map (DeMallie 2001 , p. 722). However, these villages were at most seasonal habitations located on waterways; during much of the year the people were elsewhere, engaged in hunting and other subsistence activities. Moreover, Le Sueur may simply have been replicating the Sioux naming system for these groups, each of which ends in -thun/thumwan « village » (e.g., watpáthun « river village ») (ibid., pp. 723-724). 
Commonality of language was the native criterion for defining the boundaries of Sioux society. In 1766-1767 Jonathan Carver listed eleven Sioux groups that he called bands, but the Sioux told him « that they knew not how many bands they had to the westward which they was not acquainted with for they say that the people as far as the great waters, pointing to the west, spake their tongue » (Parker 1976 , p. 101). This seems to be a clear indication both that identity as Sioux was based on language and that the eastern Sioux, at least, lacked a definite sense of the western boundary of their society. At this period, the Sioux occupied a territory that stretched from east of the Mississippi River westward to the Missouri River. Identifying Carver's "great waters » with the Missouri is a reasonable hypothesis.

According to Carver, in April 1767 the chiefs of the Sioux bands came together at a place on the Mississippi River " to hold a sort of an annual council » (Parker 1976, p. 115). The only business he reports from the council was discussion of whether to trade with traders from Canada or Louisiana, with all but one chief favoring those from Canada. Carver is unclear as to whether all the bands were represented and whether he considered this a political gathering; from his description it seems that its primary purpose related to trade. During the later decades of the eighteenth century, as the Sioux began to acquire horses and followed the buffalo herds westward on the prairies, the locus of the annual trade fair shifted west to the James River in present eastern South Dakota. By the beginning of the nineteenth century a gathering took place there each May to which the Santees, Yanktons, and Yanktonais brought large quantities of trade goods, including guns and ammunition, as well as catlinite pipes and walnut bows, to give to the Tetons in exchange for horses, tepee covers, buffalo robes, and antelope skin clothing (Moulton 1981-2001, vol. 3, pp. 412-413; Tabeau 1939, pp. 121-122). According to Tabeau, as many as 1,200 lodges came together at these gatherings.

Joseph Renville, son of a French-Canadian trader and a Dakota mother, provided much of the information recorded by missionaries and government officials about the eastern Sioux in the early and mid-nineteenth centuries. As reported by William Keating, the chronicler of Major James H. Long's expedition up the Mississippi River in 1817, Renville had a nostalgic view of a pristine past when all the Sioux were united in a political alliance, calling one another brothers and meeting in council among the Mdewakantonwan Dakotas, « the oldest band of the nation, their chiefs being of longer standing than those of the other tribes », where « they lighted the common calumet at the General Council Fire » (Keating 1959 [1825], I, pp. 442-443). With the coming of the white men their alliance fell into ruin and their defensive wars, in which they marched by the hundreds against their enemies, were reduced to bands of marauding warriors. By 1817 all that remained to commemorate past greatness was the name of their alliance, the Seven Council Fires. 
In fact, the designation ochéthi shakówin « seven fireplaces » was not recorded in the eighteenth century, but it is found throughout later accounts (see DeMallie 2005). The seven Sioux groups designated by this name are the four eastern groups (the Mdewakantonwans, Wahpetonwans, Sissetonwans, and Wahpekutes), the two intermediate groups (Yanktons and Yanktonais), and the western group (Tetons). Although they congregated annually during the early nineteenth century at the James River trade fairs, by midcentury those gatherings came to an end. Contributing to this, undoubtedly, was the increased distance required to travel as the Teton moved farther and farther west of the Missouri, and the fact that European trade goods became available on the Missouri as white traders increased their activities in the region. More and more the two extremes of Sioux society lost touch with one another. Nonetheless, common language remained the bond uniting all the Sioux, with dialectal differences characterizing the eastern, intermediate, and western groups (see Parks and DeMallie 1992)

That language was the most significant symbol of Sioux identity from native perspectives is abundantly documented in the literature. For example, a woman captured from an enemy tribe and married by a Sioux man was considered Sioux once she learned to speak her captors' language (Walker 1982, pp. 54-55). All those who spoke the Sioux language were Dakhóta (Lakhóta in the Teton dialect); the term means « allies ». Each Sioux person was potentially related to all other Sioux people in an unbounded network of kin relationships. Sioux society may therefore be conceptualized as comprising a vast network of interrelated egocentered kindreds. The Sioux term is takúkichiyapi « those related to one another ». Historically, " relating » was prerequisite for social interaction. Each pair of kin terms entailed specific patterns for behavior and affect; kin relations shaped all interactions among the Sioux. Kin terms, not personal names, were the proper form of address; therefore individuals required the establishment of relationship before engaging in discourse with one another. This could be accomplished by tracing genealogical relationship, by one or another type of formal adoption, or simply by deciding informally which kin terms to use with one another. Kin relationships of all three types carried the same moral value. Whether they were established by biological connection, marriage, or adoption, they were permanent relationships. When one person adopted another, as, for example, in the hunká ceremony, the relatives of both individuals adjusted their kin relationships accordingly, using the appropriate terms as though the adopted relationship were a genealogical one (Deloria E. 1944, pp. 24-38; DeMallie 1994).

The Lakota word designating Indians is ikcé wichásha " common men "; those who spoke the Lakota language were termed Lakhóta " allies », designating all the Sioux. All other Indians, those who did not speak the Lakota language, were called thókakichiyapi "those related to as enemies ». They were outside the bounds of Sioux social life, just as they were outside the bounds of linguistic discourse. The proper interaction with enemies was warfare; communication with 
enemies, when required, was by sign language. The Cheyennes were an exception to this generalization. In the second half of the nineteenth century they became allied with the Lakotas, and even though they spoke a different language, they were called Lakhóta Shahíyela, which may be translated both as "Cheyenne Sioux » and « Cheyenne allies ». The name Shahíyela does not originate in the Lakota language, but is a loan word common throughout the plains as a designation for groups of Algonquian speakers. The Lakotas, however, gave the term a folk etymology, sha « red » + iyá « to speak », that is, " red talkers », said to be a metaphor meaning «speakers of an alien language» (Parks 2001, p. 880). That this one group of allied non-Sioux Indians received a name based on language reinforces the significance of language as the most important symbol of social identity.

\section{The units of Sioux social life}

The nuclear family was the smallest unit of Sioux social structure. Each family had a tipi within which a small fire burned, symbolizing the family's autonomy. The living area within the tipi was circular and the fireplace, also circular, was located in the center. Ideally, the tipi doorway faced east; the place of honor where the father of the family sat was on the west side, behind the fireplace. On all ceremonial occasions the tipis comprising a camp were placed in a circle with an opening to the east as a symbolic doorway. The tipi of the leading man was located on the west side, opposite the opening to the camp, paralleling the honor place within a tipi. A council lodge, composed of two or three tipis placed side by side to form a kind of amphitheater, was located in the middle of the camp and within it the council fire burned, symbolizing the autonomy of the group. Symbolically, the camp was a great family.

Families were organized in thiyóshpaye " tipi groups », usually called bands in English, that comprised one or more bilaterally extended families. The bands were designated by names, most of which were nicknames. Bands varied in size, ranging from a few tipis to more than a hundred. Each was led by a chief, who was appointed by a council comprised of the adult men of the band. All the members of a band were related to one another, many through direct ties of descent and marriage. The core of the band was usually a group of brothers and male cousins, with their families. Membership in bands was primarily determined by residence. An individual might become a member of his father's or mother's band, or might choose membership in a different band, for example, after marriage, a man might move to his wife's band. During the buffalo-hunting period the band was the most important social unit in daily life; individuals identified themselves first with their band, which, for the prereservation Sioux, may rightly be considered the basic unit of community.

Bands lived scattered about during the winter to maximize the food supply both for the people and for their horses. As spring arrived, closely related bands 
began to join together until by midsummer large camps assembled for the annual religious ceremonies held around the Sun Dance and for communal buffalo hunts. By the mid-nineteenth century the Lakotas recognized seven groupings of bands referred to by the general term oyćte " people »; the Oglalas and Brules lived in the southern portion of Lakota territory, while the Minneconjous, Two Kettles, Sans Arcs, Hunkpapas, and the Blackfoot Sioux lived to the north. These groupings are appropriately designated tribes in English. When a tribe came together the bands camped in a great circle, each band in its accustomed place relative to the others. The chiefs of the various bands came together as a tribal council, meeting around the council fire in the council lodge located at the center of the camp circle.

Collectively, the seven tribes of Lakotas were also designated by the term oyáte " people », which in this context is frequently translated " nation ». Within the circle of the nation each tribe had its specific camping place relative to the others. Despite this normative ideology, there is no evidence that at any time all of the Lakotas came together in a single place. By the mid-nineteenth century the Lakotas comprised two-thirds of the total Sioux population and they had replicated within themselves the organization into seven social units that had earlier characterized the Sioux as a whole. After the gatherings for trade on the James River were abandoned, the western Sioux became increasingly estranged from their eastern relatives, particularly the Santees.

Before their settlement on reservations the Sioux comprised a large number of independent bands loosely organized into tribes. The criteria for membership were common language and common kinship; the symbol for community at every level was the circle, from the intimacy of a single family's tipi, to the camp circle, and finally to the broadest identity as Lakota or Dakota.

\section{The EARLy ReSERVATION PERIOD (1868 To 1934)}

The Treaty of 1868 established the Great Sioux Reservation, the area of present South Dakota west of the Missouri River, as the homeland for the Lakotas. Five administrative centers, called agencies, were established, each with a nearby military post: Grand River (later renamed Standing Rock) for the Hunkpapas and part of the Blackfoot Sioux (as well as a large group of Yanktonais); Cheyenne River for the Minneconjous, Two Kettles, Sans Arcs, and part of the Blackfoot Sioux; Red Cloud (later renamed Pine Ridge) for the Oglalas; Spotted Tail (later renamed Rosebud) for the upper Brules; and Lower Brule for the lower Brules. For purposes of the treaty, everyone who lived in the camps of these Sioux tribes, whatever their origin, was considered to be included under the provisions of the treaty. Sioux leaders protested when the treaty commissioners suggested establishing a separate reservation for the mixed-blood offspring of white men and Indian women, arguing that they were relatives and were necessary 
as interpreters and intermediaries with the white men. In fact, the Lakota designation for mixed bloods, iyéska, literally means « interpreters ». Under the treaty, both mixed bloods and their non-Indian fathers living with the Sioux became legally Indian.

Throughout the treaty-making period, starting in 1851 and continuing through a series of treaties in the 1860s that culminated in the Treaty of 1868 , government officials dealt with the Sioux through chiefs. In 1851 the treaty commissioners insisted that all the Sioux present at the treaty council agree on a single head chief. Inevitably, the man selected for that position failed to live up to the US government's idea of a chief, since he had no authority to command obedience. In 1856, at another treaty council, the government also recognized a head chief and subchiefs for each of the Sioux tribes. One function of the chiefs was to oversee the distribution of goods and food provided by the government in accordance with the treaties to the members of their respective bands. This system proved efficient for signing treaties but both the Indian Office and Army soon realized that by the very act of recognizing these men as leaders they had invested them with a kind of incipient authority that they might use to direct their people against the government's wishes, as well as for them. Soon after the establishment of the reservation, government officials reversed their tactics and sought ways to minimize the role of the chiefs, perceiving their developing political power as an obstacle to assimiliation. The first step was to pay equal attention to the chiefs of small bands as was paid to such prominent chiefs as Red Cloud and Spotted Tail. Indian agents fostered jealousies among the chiefs in an attempt to weaken their authority. The agency records show a dramatic increase in the number of bands as the agents recognized the leaders of the smaller bands.

By 1881, with most of the Lakotas living within the boundaries of the reservation, the Indian agents set out to break up the bands in the belief that destroying the basis of community life would make the Indians easier to control and would encourage them as independent farmers. Goods and rations were no longer distributed through the chiefs. Instead, each head of household was issued a ticket designating the quantity to which the family was entitled. Band-based communities developed, many of which were distant from the agencies. To obviate the need for people to travel to the agencies biweekly or monthly, subagencies were established to oversee the districts and distribute rations. Government employees at the subagencies, known as "boss farmers", also provided hands-on advice and aid to Indian farmers.

In 1889 the Great Sioux Reservation was dissolved; more than half the land was opened for settlement by non-Indians and five smaller reservations were created, centered around the five agencies. The Indian Office treated each reservation as a distinct tribe, thereby creating a set of newly imposed social units. For example, Standing Rock Reservation was home to two of the old Teton tribes - the Hunkpapas and part of the Blackfoot Sioux (Lakota speakers) - as well as 
to a portion of the upper Yanktonais (Dakota speakers). The Tetons and upper Yanktonais had little in common, making their designation as the Standing Rock Sioux Tribe problematical. In fact, none of the reservations was entirely limited to a single one of the old tribes, given patterns of intermarriage and the fluid way in which bands moved about. During the period of the Sioux wars with the US Army, from 1862 to 1881, a number of bands of Santee, Yankton, and Yanktonai Sioux moved across the Missouri and joined various of the Teton tribes as they pressed west into Montana in search of buffalo hunting grounds.

On each reservation, tribal councils comprised of leading men from the various communities were established as a forum for discussing issues of general concern. When Indian agents found these councils unwieldy and difficult to control they sidestepped them by appointing small business councils for such purposes as signing land lease agreements. Indian Office regulations also called for the establishment of reservation police forces and Courts of Indian Offenses, primarily to maintain order and to control infractions of rules. All of these institutions reinforced the political autonomy of the reservation. The agents made an annual census of each reservation, keeping track of births and deaths. Indians were not allowed to leave the reservation without a written pass, and moving to another reservation required an official transfer.

In the early years of the twentieth century families were assigned surnames, both to move the Sioux along on the path to civilization and for ease of bureaucratic record keeping. This established the primacy of the father as family head and made family membership and inheritance easier to track. Along with the annual census that kept track of births, deaths, and marriages, an important aspect of reservation bureaucracy was keeping a record of each individual's degree of Indian « blood ». After establishing individuals' blood quantum on the early censuses, subsequent records documented the degree of Indian blood of their descendants.

By the early twentieth century the racial classification implied in keeping track of blood quantum had become an integral part of government officials' thinking about Indian affairs. For the Sioux themselves, however, the biological basis for this classification was not definitive. Identity as full blood came to be symbolic of commitment to tradition while mixed blood symbolized the desire to adapt to mainstream American culture, primarily as ranchers or farmers.

During the first decade of the twentieth century the Indian Office restricted the distribution of rations to the old and infirm, and instituted instead a system of hiring able-bodied men to perform such jobs as hauling freight, building roads, and tending livestock. With the money earned they could buy food for their families. The intention was to instil in the Lakotas a work ethic that would enable their transition to independence.

Between 1905 and 1911 lands were allotted to every Lakota man, woman, and child. Related individuals chose allotments adjacent to one another and formed 
dispersed communities in the areas around the subagencies. Government policy assumed that the pride of land ownership would hurry the Indians along the path to independence. Lands in excess of what was needed at the time were opened to non-Indian settlement. Perhaps reflecting the belief that Indians were a dying race, no consideration was given to the needs of succeeding generations. The old communities became permanently spread out across the reservation lands, weakening the social bonds that were central to prereservation life. Some of these communities formed around subagencies or " boss farmers' » houses where rations were issued. Others formed around day schools. In each community a church was built, which became the focus of the community. Representing a variety of denominations, the churches seem to have been especially important for their cemeteries, providing the final resting place for community members.

In 1906 the Burke Act laid the groundwork for granting citizenship to Indians who had received allotments and were judged " competent » to manage their own affairs (Prucha 1977, p. 207). Individuals were subsequently responsible for paying taxes, which led many to sell or forfeit their lands. Indians who had half or more white blood came to be judged as competent on that basis alone. In 1917, Commissioner of Indian Affairs Cato Sells articulated the policy of "releasing " most half-blood Indians from government wardship while at the same time declaring that blood quantum was not « always a safe standard » (Prucha 1977, pp. 213-214). The inevitable result was massive land loss, with little or nothing for the newly enfranchised Indians to show in return for it.

Beginning in the 1880 s at least some Lakota children attended reservation schools, developing into the first generation to speak English. At the same time, native religious and social practices were prohibited by the Indian Office. Fourth of July celebrations, agricultural fairs, rodeos, and church encampments replaced the Sun Dance as foci of summer activities. Many Sioux people gained direct knowledge of white culture by traveling with wild west shows, both in the United States and abroad, and by performing dances and participating in parades in off-reservation towns and cities. At the same time, many Sioux children were attending off-reservation boarding schools where they not only learned about the white men and their ways of life, but also interacted and ultimately intermarried with students from other tribes. In the process, ideas and practices were exchanged and a generalized identity as Indian developed, which was fostered by the teachers, who perceived Indian and White as a fundamental opposition. Similarly, some Sioux men joined the armed forces in World War I and returned to the reservations with a broader perspective on the world. English began to be commonly used, particularly in intertribal contexts.

During the early reservation period, language remained an important marker for Sioux identity, but the development of politicized tribes, together with bureaucratic record keeping based on Euro-American concepts, increasingly 
defined tribal membership genealogically. The reference community, however, remained the band, first transformed into sedentary villages as the old tipi encampments were replaced by clusters of log houses, then into districts as individual families moved onto their allotments. Although weakened, these geographically dispersed communities retained the kinship networks of the traditional bands and the leading men now served as councilmen at the tribal level. The pattern of long-term visiting, as in prereservation times, also contributed to kin solidarity; such visits might last weeks or even months.

\section{The period of the Indian reorganization aCt and relocation (1934- 1961)}

The inauguration of Franklin D. Roosevelt as president of the United States in 1933 heralded a period of intense governmental reform and increased social programs. For American Indians, the "Indian New Deal » was embodied in legislation known as the Indian Reorganization Act (IRA), which was passed by Congress in 1934. By giving tribes the opportunity to write constitutions as political entities and to incorporate for economic purposes, the IRA sought to institute both representative democracy and economic independence on the reservations. At the same time, under the leadership of Commissioner of Indian Affairs John Collier, the Office of Indian Affairs sought to encourage tribes in the expression of their traditional cultures, languages, religions, and social organizations. Although H. Scudder Mekeel, Collier's anthropological advisor among the Sioux, pressed for the importance of making the old bands the basis for electoral units, the pre-IRA political system had been based on the districts that had formed around the subagencies. These districts were geographical units, not social ones. Each district was defined by a watershed within which a number of communities were located; given the poorly developed reservation roads, it was difficult to cross from one watershed to the next in inclement weather. In the end, on Pine Ridge Reservation, the old districts were written into the new constitution as the electoral units; in contrast, the Rosebud and Cheyenne River constitutions defined new electoral units based on communities, although some communities were combined with others in electoral units (Biolsi 1992, pp. 104-108). Overall, the IRA tribal constitutions did a poor job of incorporating the significant social units, especially on the larger reservations, in part because they assumed that each community, however defined, had a unified political interest that could be represented by an elected councilman. This policy ignored the contentious nature of Lakota political life and meant in practice that many Lakotas would complain that their elected councilman was concerned only with his own welfare, or that of his relatives, and not those of the other families he was supposed to represent. 
The institution of representative democracy brought with it the first glimmers of political power available to reservation leaders. Until then, tribal councils had been largely symbolic, and business councils had functioned solely to ratify the actions of the Indian agents. The councils were dominated by full-blood Lakotas while the mixed bloods distanced themselves from the tribes. During allotment, mixed bloods tended to select the best lands for ranching and farming and formed communities that were separate from the old band communities. They had relatively little to do with other tribal members and identity as mixed blood came to be seen in opposition to Indian, rather than as a subset of it. With the IRA, however, mixed bloods were drawn into the political arena and began to participate actively in tribal affairs; many of the first generation of tribal politicians under the IRA were mixed bloods. In protest, older, more culturally conservative Lakotas dubbed themselves « Old Dealers » and vigorously protested the mixed bloods' dominance. During this period, ethnic identity became a focus of contention as relations between those identified as full bloods and those identified as mixed bloods degenerated into an unprecedented social opposition that continues to be a permanent tension in tribal life (Robertson 2002, pp. 172-176).

Federally sponsored social programs such as the Civilian Conservation Corps-Indian Division to some degree alleviated poverty and anomie on the reservations. World War II brought a real change as many Lakota men enlisted in the armed forces and saw duty overseas. At the same time, many Lakota women migrated temporarily to urban areas to participate in war-related industries. These experiences helped to break down the isolation of the reservations. After the war, government policy changed, reacting against the social programs of the New Deal era. Instead of fostering economic development on the reservations, Indians were encouraged to relocate to major urban centers such as Chicago, Denver, and Los Angeles. Provided with little more than bus fare and help finding a place to live and a job, many Lakotas made the move. Some stayed in the city and adapted economically and socially to urban life; some developed a pattern of moving back and forth between urban areas and the reservation; but many more abandoned the city and returned to their reservations (Christafferson 2002, pp. 821-824).

The mobility of this period put new strains on Lakota communities and kin networks. While politically the "tribes ", that is, the larger social units that comprised each reservation, gained in significance, the dispersion of tribal members served to draw individuals away from tribal loyalties. In the cities, Lakotas found a new significance to their identity as Indians, the category - defined both as an ethnic and a racial category - into which they found themselves classified by non-Indians. Differences of tribe, language, and culture mattered less in the urban context than the oppositional commonality of Indian identity. This identity took expression in urban Indian centers that served to create social and economic alliances among members of many tribes. Intertribal marriages resul- 
ted, and urban communities developed common rituals - most notably the pantribal powwow - both for in-group entertainment and as an expression of their Indian identity.

On the reservations, during this period, the local communities, representing traditional bands, continued to dominate social identity. However, tribal identity seems to have been increasing in importance both internally, as political opportunities grew in significance, and externally, as individuals outside the reservations dealt with members of other tribes. With the IRA constitutions, the reservation-based tribes (such as Pine Ridge and Cheyenne River) served as the fundamental units of social identity. Generalized identity as Lakota or Sioux seems to have become less significant, while "Indian », as an ethnic marker, developed greater prominence in the expression of identity. Language seems to have diminished in importance as a marker of identity among mixed bloods, though it remained an important symbol for full bloods. Kin relationships continued to be central to social life, though in a more restricted way than in traditional society as nuclear families developed greater economic independence and the traditional pattern of social relations based on common residence and sharing of resources was disrupted.

\section{THE PERIOD OF SELF-DETERMINATION (1961 To THE PRESENT)}

In June 1961 more than five hundred Indians representing some ninety tribes came to the campus of the University of Chicago to attend the American Indian Chicago Conference. Conceptualized by Sol Tax, an anthropologist at the University of Chicago, and endorsed by both the National Congress of American Indians and the American Anthropological Association, the purpose of the conference was to develop a position paper expressing contemporary Indians' social, political, and economic concerns, and to suggest directions to address them. The attendees included both traditional elders and young activists, reservation dwellers and urban Indians, and those with degrees in higher education as well as those whose expertise was based entirely on life experience. The document they produced was called the " Declaration of American Indian Purpose », and its most pressing message was that Indian people wanted to perpetuate their existence as Indians, not lose themselves in mainstream America (Ablon 1979; Lurie 1961).

The social programs initiated under the presidencies of John F. Kennedy and Lyndon B. Johnson infused reservation economies with much-needed money that provided Indians with greater opportunities for employment with the tribes and with social and economic programs. As a result, those who represented what was effectively the first generation of college-educated Indians were enabled to return to their reservations and find employment. Among the Sioux, this led to the 
establishment of Indian-controlled school boards, the institution of classes for teaching Lakota language and culture, and the founding of tribal colleges that were designed to ease nontraditional students into higher education and to serve as a means of preserving and perpetuating Lakota language and culture.

The expression of traditional culture, and in particular the performance of traditional rituals, increased greatly during this period. In prereservation times the annual Sun Dance, which was not only the most important sacred ritual but also the most important social gathering of the year, brought together the scattered bands for a few weeks of tribal ceremonies and communal buffalo hunts. In 1881 the Sun Dance was banned by the government, in large part because it involved self-sacrifice in the form of male dancers piercing their flesh. After 1934, the year of the Indian Bureau's declaration of Indian Religious Freedom, the Sun Dance began to be practiced again openly, although in truncated form, usually in association with a summer fair and rodeo. These reenactments lacked the mortification of flesh that had so offended non-Indians. Then in 1961, a Lakota man who had returned from California where he had gone on the Relocation program had his chest pierced in the traditional manner and had to struggle against the rope attached to the center pole to free himself. For the next decade Sun Dances were held annually at Rosebud and Pine Ridge Reservations, attracting large crowds from other reservations and urban areas. By the mid1970s these tribal Sun Dances, expressing the solidarity of the entire reservation as a community, were largely replaced by a growing number of smaller, local community or family-based Sun Dances. The largest Sun Dances were sponsored by the American Indian Movement, which particularly attracted urban Indians, many of them not Sioux. In this way, while the link between participants in traditional religious ceremonies and the reservations as tribal communities was severed, the Sun Dance expanded to provide opportunities for the incorporation of wider social networks. More and more, Lakotas turned away from the Christian churches and embraced traditional religion based on the sacred pipe. In the twenty-first century, traditional religion is perhaps the most important symbol of Lakota identity, and is expressed publicly by participation in such rituals as the sweat lodge.

Annual celebrations focused around powwow dancing, including giveaways and rodeos, remain important expressions of community solidarity. The calendar of summer weekends on each reservation forms a litany of celebrations that move from one community to another, communities vying with one another for the number of dancers, the lavishness of giveaways, and the abundance of food for the visitors, who camp out around the dance arenas. The culminating expressions of tribal unity are the reservation-wide celebrations and tribal fairs that attract large crowds. Like Sun Dances of old, they offer opportunities for renewing social ties and for forming new ones. The awarding of prize money to the drum groups and dancers judged to be the best attracts participants from tribes throughout the 
west, not only the Sioux. Many of the powwow dancers and their families travel about throughout the summer from one celebration to the next, competing for prize money to subsidize their travels. They form a strong force in the emergence of what has been called "panIndianism » (in fact, pantribalism) that fosters a generalized ethnic identity as Indian. Outside the northern plains reservations - for example, in Oklahoma, in urban areas, and in the region east of the Mississippi River -, Indian identity, expressed by participation in powwows, became essential for forging bonds of common interest in the face of mainstream American society.

Marriages between individuals from different Sioux reservations had been common from the beginning, and intertribal marriages - often resulting from relationships that developed in boarding schools - had long been characteristic. After World War II, off-reservation opportunities to meet Indians from many different tribes and to socialize with non-Indians increased in frequency as Sioux people moved to urban areas on Relocation, attended college, or served in the military. At the same time, on the reservations, YMCA, VISTA, and other volunteer workers came in increasing numbers, introducing new elements from the wider American culture. In the families that resulted from marriages with outsiders, English came to be spoken in the home. In 1965 seventy-five percent of the reservation Sioux were estimated to be Lakota speakers; by 1990 only twenty-five percent used Lakota to any extent (Parks and DeMallie 2006, p. 198).

While the decline of native language signaled a weakening of tribal identity, the Indian Self-Determination and Educational Assistance Act of 1975 provided a pull toward tribal identity and the definition and exercise of tribal sovereignty, which is today the central issue in American Indian political life. Indian lawyers have pursued cases in federal courts to protect land rights and hunting and fishing rights; tribal courts have sought to exercise tribal sovereignty in local cases. Aided by the profits generated from tribal casinos established on most of the Sioux reservations in the 1980 s and 1990 s, reservation tribal councils have had more funds to undertake projects of their choice. Most tribal colleges on Sioux reservations have grown and prospered, and many reservations have established tribal museums, cultural centers, and cultural resource management programs. Increasingly, people have moved from the small rural communities that descended from traditional bands to the larger reservation towns, which include nonIndian populations as well. The primary bonds of identity seem to be shifting from the older communities to the tribe as a political unit.

At the same time, the growing numbers of Indians with higher education degrees in law, education, and a wide variety of academic disciplines have become a clear voice for intellectual self-determination. Prominent among them was Vine Deloria, Jr., a member of the Standing Rock Sioux Tribe, whose Custer died for your sins: an Indian manifesto (1969), asserted what came to be called « Red Power », a declaration that American Indians continued to exist in modern 
America and that they were ready to speak and act for themselves. Rejecting the paternalism of government officials, church leaders, and anthropologists - no matter how well-meaning -, Deloria called for retribalization, a strengthening of American Indian reservation communities, and the development of a kind of Indian nationalism in urban centers, where the majority of American Indians were living. Basic to his argument were the rights guaranteed to Indians by the many treaties signed by the United States in good faith with tribes as sovereign nations.

Growing out of the effort to assert treaty rights, representatives of the various Sioux reservations have come together as the Seven Council Fires, calling for a unity of purpose among all the Sioux under the designation of the Dakota, Nakota, and Lakota Nation. The group descends from the Black Hills Treaty Council, a pan-Sioux organization that originated in the 1890s with the purpose of persuading the government to live up to its responsibilities under the Treaty of 1868 and return the Black Hills to the Sioux. Although Congress appropriated a monetary reward to settle the claim, the Sioux have been unwilling to take the money and instead continue to seek the return of land (Christafferson 2001, pp. 836-838). This expression of nationhood represents the degree to which, since the beginning of the reservation period, common identity as Sioux has transformed from ethnic identity to political identity.

In the first years of the twenty-first century, as Indian scholars explore the possibilities of political sovereignty and cultural self-determination, a rhetoric of « decolonializing the academy » (Mihesuah and Wilson 2004) or Radical Indigenism (Garroutte 2003) has been forcefully articulated. The premise is that nonIndians have controlled what has been written and published about Indians for four centuries; consequently, those who speak from this perspective proclaim that the time has come for Indians to take control of the written word, just as, with the Native American Graves Protection and Repatriation Act of 1990, they gained control of what is kept and displayed in museums. Indian or Native American in this context is an identity forged in opposition to White - meaning mainstream America. Phrased in this manner, the dichotomy seems to be based on a concept of race borrowed from American culture, although Eva Marie Garoutte (2003, pp. 121-122) argues that such an " essentialist » perspective derives from tribal traditions. In effect, after centuries of being stigmatized by Euro-Americans as an inferior " race ", some Native American intellectuals are coopting the concept of race to use as a weapon against perceived oppression. Concomitant with this emphasis on race is the public expression of a rhetoric of grief (and its obverse, blame), understood as the product of generations-old trauma resulting from the Euro-Americans' ruthless appropriation of the New World and their subjugation of Indian peoples, physically and psychologically. From the nineteenth throughout much of the twentieth century, Indians learned from non-Indians to be ashamed of who they were, racially, culturally, and linguistically. This psycholo- 
gical burden is perceived as an impediment to progress as Indians now strive to recover traditional values, customs, and language.

Many Sioux individuals have played pivotal roles in the developments leading toward self-determination. In the process they have shifted their communities of reference from the local to the tribal or intertribal. This is not to imply that kinship ties are no longer important, but the circle of kin and the dimensions of sharing have narrowed as individuals and families become enmeshed in the American economic system. Out of necessity, native language has been abandoned as a criterion for group membership, although the value of preserving the language in order to perpetuate the culture is widely held. However, today, when less than ten percent of reservation Sioux speak the native language fluently, few families are willing to place language learning and language use as a priority in daily life. Nonetheless, language loss is widely bemoaned as heralding the loss of traditional culture.

At the same time that tribes as political entities have replaced tribes as ethnic entities as foci of reference, communities have been defined more explicitly in terms of polities than in terms of residence. Commonality of interest may be greater across tribal boundaries than within tribes. The Black Hills Treaty Council exemplifies this within the Sioux tribes. For those Sioux individuals who have chosen careers in academia, law, or journalism, the wider community of their peers throughout «Indian country » - an imagined community of Indians of all tribes - is the primary reference group. In this instance, Indian is increasingly defined in terms of race (that is, Indian «blood ») rather than in terms of politics (membership in federally recognized tribes).

\section{Summary}

During the past two centuries, among the Sioux, the trajectory of community and the definition of who is and is not a member of the community has shifted from native criteria to those imposed by Euro-Americans and back again. In the prereservation period, language was the preeminent symbol of ethnicity and physical residence in a social group was the main criterion of membership. The circle served as the outward symbol of social unity; within the circle all were relatives. Among the Lakotas, seven groups of related bands, the seven tribes that comprise the Teton Sioux (Lakotas), developed as political entities. During the early reservation period, the Sioux tribes were localized on different reservations that, in turn, became politicized and reified as tribes in the sense recognized by the government of the United States - that is, as quasi-sovereign nations. Tribal membership came to be defined by genealogy rather than residence, but the definition of community continued to revolve around common culture and common kinship. The period beginning with the Indian Reorganization Act 
brought greater solidarity to the tribes as political and economic entities; wide differences of interest and culture between full bloods and mixed bloods came more into focus in the political arena. Language ceased to be essential to community membership. During the last decades, the period of selfdetermination, politics and religion have continued to dominate as the major expressions of community. For some of those living on the reservations, community still refers to the band-based communities from the past, many of which comprise little more than housing tracts. For others, such as tribal politicians, the tribe, that is the reservation as a whole, is the fundamental community. For others still, such as the graduates of higher education, the community of American Indians in its broadest sense - Native Americans, First Nations - has emerged as the increasingly important social group.

The reality of community today is far from Redfield's ideal-type "little community ", but the moral sense underlying community as a social unit has much the same sense. For the Sioux, the circle, « the hoop of the nation » [quoting John G. Neihardt (1932) interpreting the Oglala Lakota holy man Black Elk] remains a potent symbol that embraces kinship, community, religion, ethnicity, and race. The expression of that symbol and the meanings emphasized are individual decisions that vary with the audience and the intent. The continuity of this symbol across the centuries of recorded history is an impressive reminder that at the deepest levels, continuity underlies change throughout Native North America.

The Sioux case demonstrates the value of taking an ethnohistorical perspective on American Indian cultures. The continuity that we have detected links the contemporary Sioux directly to their past and draws on enduring values to confront present realities. For the Sioux, the overwhelming value of community is as a locus of kin, a place of safety and support. Kin relations define the basis of community, but the physical nature of that community has been constantly changing throughout more than three centuries of recorded history. Communities feel primordial to their members, but the historical processes by which they come into being reveal constant change. In prereservation times, bands dissolved and reformed following the fortunes of their leaders. Movement of disaffected families or individuals from one band to another provided the ultimate means of dispute resolution. On the reservations such mobility was impossible given the allotment system, which was designed to create permanent bonds between individual nuclear families and particular parcels of land. With the failure of that system through individuals' land loss, new types of communities developed around subagencies, schools, and churches. Based on extended families, they continued relatively traditional social forms through most of the twentieth century. But economic necessity and cultural change are leading the Sioux away from their small, face-to-face communities, and into the relative anonymity of the town or city. The resulting challenges to preserving tribal community are great 
and involve compromises between traditional culture and the modern world. Mediating that divide is a renewed reliance on traditional religious beliefs and practices, which provides spiritual support and tribal identity in the context of modern America. New forms of community, some residential and others based on periodic return to reservation homelands during life, and ultimately in death, will develop and provide social stability to the Lakotas in the twentyfirst century. *

* Manuscrit reçu en septembre 2007, accepté pour publication en janvier 2008.

\section{NOTES}

Acknowledgments: an earlier version of this paper was presented at the colloquium « Des catégories et de leurs usages dans la construction sociale d'un groupe de réference: "race", "ethnie" et "communauté" aux Amériques ", EHESS, Paris, December 2006. I am grateful to the commentators, Isabelle Schulte-Tenckhoff and Gilles Rivière, for their helpful remarks on the presentation. In revising the paper for publication I am especially indebted to Raymond A. Bucko for his detailed comments and criticism, which have greatly improved it. I owe thanks as well to many colleagues for their contributions to the writing of this paper, especially Emmanuel Désveaux, David Reed Miller, Sebastian Felix Braun, Jason Baird Jackson, Kelly Branam, David C. Posthumus, and Theresa Schenck.

\section{REFERENCES CITED}

AbLon Joan

1979 «The American Indian Chicago conference », in Robert Hinshaw (ed.), Currents in anthropology: essays in honor of Sol Tax, Mouton, The Hague, pp. 445-456.

\section{BioLsi Thomas}

1992 Organizing the Lakota: the political economy of the New Deal on the Pine Ridge and Rosebud Reservations, University of Arizona Press, Tucson.

ChristafFerson Dennis M.

2001 "Sioux, 1920-2000", in William C. Sturtevant (gen. ed.) and Raymond J. DeMallie (vol. ed.), Handbook of North American Indians. Vol. 13 : Plains, Smithsonian Institution, Washington, DC, pp. 821-839.

Creed Gerald W. (ed.)

2006 The seductions of community: emancipations, oppressions, quandaries, School of American Research Press, Santa Fe, New Mexico.

DelisLe Claude

1702 "Memoires de Mr Le Sueur [1699-1702] », Archives de la marine, Ms. No. 2JJ56-9, Archives nationales, Paris.

Deloria Ella

1944 Speaking of Indians, Friendship Press, New York. 
Deloria Vine, Jr.

1969 Custer Died for your sins: an Indian manifesto, Macmillan, New York.

DeMallie Raymond J.

1994 "Kinship and biology in Sioux culture », in Raymond J. DeMallie and Alfonso Ortiz (eds), North American Indian anthropology: essays on society and culture, University of Oklahoma Press, Norman, pp. 125-146.

2001 «Sioux until $1850 »$, in William C. Sturtevant (gen. ed.) and Raymond J. DeMallie (vol. ed.), Handbook of North American Indians. Vol. 13 : Plains, Smithsonian Institution, Washington, DC, pp. 718-760.

2005 "The Sioux at the time of European contact: an ethnohistorical problem », in Sergei A. Kan and Pauline Turner Strong (eds), New perspectives on native North America: cultures, histories, and representations, University of Nebraska Press, Lincoln, pp. 239-260.

DURKHEIM Émile

1947 The division of labor in society, translated by George Simpson, Free Press, Glencoe [De la division du travail social, 1893].

Garroutte Eva Marie

2003 Real Indians: identity and the survival of native America, University of California Press, Berkeley and Los Angeles.

KeAting William H.

1959 Narrative of an expedition to the source of St. Peter's River, Lake Winnepeek, Lake of the Woods, \& c. Performed in the year 1823, by order of the Hon J. C. Calhoun, secretary of war, under the command of Stephen H. Long, U.S.T.E., London/Ross \& Haines, Minneapolis, Minn., reprint [1825].

LuRIE Nancy O.

1961 "The voice of the American Indian: report on the American Indian Chicago conference », Current Anthropology, 11, pp. 478-500.

Minesuah Devon Abbott and Angela Cavender WiLson (eds)

2004 Indigenizing the Academy: transforming scholarship and empowering communities, University of Nebraska Press, Lincoln.

Moulton Gary (ed.)

1981-2001 Journals of the Lewis and Clark expedition, 13 vols, University of Nebraska Press, Linoln.

NeIHARDT John G.

1932 Black Elk speaks: being the life story of a holy man of the Ogalala Sioux, Morrow, New York.

PARKER John (ed.)

1976 The journals of Jonathan Carver and related documents 1766-1770, Minnesota Historical Society Press, Saint Paul. 
Parks Douglas R.

2001 "[Cheyenne] synonymy ", in William C. Sturtevant (gen. ed.) and Raymond J. DeMallie (vol. ed.), Handbook of North American Indians. Vol. 13 : Plains, Smithsonian Institution, Washington, DC, pp. 880-884.

Parks Douglas R. and Raymond J. DeMallie

1992 "Sioux, Assiniboine, and Stoney dialects: a classification ", Anthropological Linguistics, 34 (1-4), pp. 233-255.

2006 "Native languages of the Plains Indians of North America ", in Christian Gros and Marie-Claude Strigler (eds), Être indien dans les Amériques, Éditions de l'Institut des Amériques, Paris, pp. 197-207.

Prucha Francis Paul

1977 Documents of American Indian history, University of Nebraska Press, Lincoln.

REDFIELD Robert

1960 The little community and peasant society and culture, University of Chicago Press, Chicago.

RoBERTSON Paul

2002 The power of the land: identity, ethnicity, and class among the Oglala Lakota, Routledge, New York and London.

TABEAU Pierre-Antoine

1939 Tabeau's narrative of Loisel's expedition to the Upper Missouri, edited by Annie Heloise Abel, University of Oklahoma Press, Norman.

WALKer James R.

1982 Lakota society, edited by Raymond J. DeMallie, University of Nebraska Press, Lincoln. 